University of Nebraska - Lincoln

DigitalCommons@University of Nebraska - Lincoln

Faculty Publications from the Harold W. Manter Laboratory of Parasitology

7-1981

\title{
The Coccidia of Quail in the United States
}

Donald W. Duszynski

University of New Mexico, eimeria@unm.edu

Ralph J. Guttiérrez

Humboldt State University

Follow this and additional works at: https://digitalcommons.unl.edu/parasitologyfacpubs

Part of the Parasitology Commons

Duszynski, Donald W. and Guttiérrez, Ralph J., "The Coccidia of Quail in the United States" (1981). Faculty Publications from the Harold W. Manter Laboratory of Parasitology. 189.

https://digitalcommons.unl.edu/parasitologyfacpubs/189

This Article is brought to you for free and open access by the Parasitology, Harold W. Manter Laboratory of at DigitalCommons@University of Nebraska - Lincoln. It has been accepted for inclusion in Faculty Publications from the Harold W. Manter Laboratory of Parasitology by an authorized administrator of DigitalCommons@University of Nebraska - Lincoln. 


\title{
THE COCCIDIA OF QUAIL IN THE UNITED STATES
}

DONALD W. DUSZYNSKI, Department of Biology. The University of New Mexico, Albuquerque, New Mexico 87131, USA.

RALPH J. GUTIÉRREZ, Department of Wildlife Management, Humboldt State University, Arcata, California 95521, USA.

\begin{abstract}
Intestinal contents from 12 scaled quail (Callipepla squamata), 10 bobwhite quail (Colinus virginianus), 20 harlequin quail (Cyrtonyx montezumae), 35 California quail (Lophortyx californicus), 15 Gambel's quail (Lophortyx gambelii), and 29 mountain quail (Oreortyx pictus) were examined for coccidian oocysts. Only 18 (14.9\%) of 121 birds had coccidian oocysts in their feces at the time of collection; these included $9 \mathrm{~L}$. californicus and $9 \mathrm{O}$. pictus. Four eimerians and an isosporan were found in the 18 infected birds. Eimeria lophortygis and E. okanaganensis had been previously described from $L$. californicus, but were also seen in $O$. pictus. Eimeria crusti $\mathbf{s p .}$. and Eimeria oreortygis sp. n. are described from $O$. pictus; $E$. oreortygis was also found in $L$. californicus. Broadly ellipsoid oocysts of $E$. crusti had a rough outer wall, were $26.0 \times 21.2(24-28 \times 20-23) \mu \mathrm{m}$, and contained ovoid sporocysts $15.7 \times$ $7.5(14-18 \times 7-8) \mu \mathrm{m}$. Micropyle and oocyst residuum were absent but a polar granule, sporocyst residuum, Stieda and substieda bodies were present. Slightly ovoid oocysts of $E$. oreortygis had a smooth outer wall, were $24.4 \times 18.7(21-28 \times 17-23) \mu \mathrm{m}$, and contained ovoid sporocysts $14.1 \times 7.2(13-16 \times 6-9) \mu \mathrm{m}$. Micropyle and polar granules were absent but a small oocyst residuum, large sporocyst residuum, Stieda and substieda bodies were present. Oocysts of an isosporan were found and compared to oocysts of Isospora lacazei isolated from sparrows in a previous study.
\end{abstract}

\section{INTRODUCTION}

Quail are important game birds in the United States, particularly in the South and Southwest. For example, more bobwhite are killed in the South than all other upland game birds in the U.S.A. Although it has been known that coccidians infect quail since Tyzzer.3.3 described Eimeria dispersa from the bobwhite and turkey, concerted efforts to determine the species that infect our endemic quail species are rare. This is surprising since all six host species (in five genera) endemic in the United States are found in the Southwest (including Southern California) and several of them are sympatric. Information from sympatric species should prove useful since eimerians from most birds are thought to be highly host specific with hosts belonging only to closely related genera susceptible to each other's coccidia.
Between 1974 and 1976 , over 175 quail including bobwhite quail (Colinus virginianus), California quail (Lophortyx californicus), Gambel's quail (L. gambelii), harlequin quail (Cyrtonyx montezumae), mountain quail (Oreortyx pictus) and scaled quail (Callipepla squamata) were observed, collected and examined to study the comparative ecology and systematic relationships of the various species. ${ }^{3,4}$ Intestinal contents from 121 of these birds were preserved and later examined for the presence of coccidian oocysts. The results of this part of the overall study are described herein.

\section{MATERIALS AND METHODS}

All birds sampled were from wild populations, and were classified as either adult males and females or as juveniles 
(non-breeding subadult 5 mo old). The birds were shot and fecal samples were taken from the lower $8 \mathrm{~cm}$ of the digestive tract of each bird. Most samples were collected within a few hours of death, but in a few instances, some dead birds were kept at $5 \mathrm{C}$ for $24 \mathrm{~h}$ until they could be dissected and the feces collected. In all cases the feces were placed in a vial in $3 \%$ aqueous $(\mathrm{w} / \mathrm{v}) \mathrm{K}_{2} \mathrm{Cr}_{2} \mathrm{O}_{i}$ and stored at $4-5$ $\mathrm{C}$ until they could be shipped via air freight to Albuquerque. Upon arrival in Albuquerque the samples were again refrigerated $(5 \mathrm{C})$ until they could be filtered (20-, 40- and 60-mesh brass screens) and examined for oocysts by coverslip flotation in concentrated sucrose solution (sp. gr. 1.15). Oocysts were measured with an ocular micrometer and photographed with Kodak Pan-X (ASA 32) and Ilford Pan-F (ASA 50) film in a Zeiss universal photomicroscope equipped with a $100 \mathrm{X}$ neofluar objective. All measurements are in micrometers $(\mu \mathrm{m})$ with the range in parenthesis following the mean.

\section{RESULTS}

\section{Coccidians}

Four eimerians and one isosporan were found in the quail examined. Of these, Eimeria lophortygis and E. okanaganensis have been described previously from Lophortyx californicus by Liburd and Mahrt.1: The other two eimerians are described below as new species. The specific status of the isosporan is discussed.

Eimeria crusti sp. n. (Figs. 1-3)

Description. Oocyst broadly ellipsoid to subspherical; wall 1.6 consisting of 2 layers: outer $3 / 4$ of total wall thickness, irregularly sculptured, yellow-brown, always seen with adherent debris (Fig. 3 ); inner layer smooth, thin, yellowish; micropyle absent although wall sometimes seemed thinner at 1 end (Fig. 1 ); oocyst residuum absent; polar granule present $\sim 1 \times 3$ (Figs. 1, 2); sporulated oocysts $(\mathrm{N}-44) 26.0 \times 21.2(24-28 \times 2()-23)$ with $\mathrm{L}: \mathrm{W}$ ratio $1.23(1.10-1.32)$; sporocysts ovoid, $15.7 \times 7.5(14-18 \times 7-8)$ with $\mathrm{L}: \mathrm{W}$ ratio 2.10 (1.78-2.45); Stieda and substieda bodies present (Fig. 2); sporocyst residuum of small granules as compact mass $\sim 3 \times 6$ or scattered throughout sporocyst; sporozoites with 1 large refractile body. The oocysts were 1475 days old when measured.

Type Host. Oreortyx pictus (Douglas, 1829): mountain quail.

Type Locality. Monterey County, California.

Location in Host. Unknown; oocysts recovered from feces.

Etymology. The specific name is derived from the Latin root, crust, a tough, hard surface; it refers to the thick, rough outer wall of the oocyst.

Remarks. Eimeria crusti resembles $E$. colini described from the bobwhite quail, Colinus virginianus by Fisher and Kelley² but differs by the presence of a polar granule, and the size and shape of the sporocyst and sporocyst residuum. From another study on genic variation using allozyme electrophoresis,' we know that $O$. pictus more closely resembles $C$. virginianus than any other quail species.

Eimeria lophortygis (Figs. 4, 5)

Remarks. We measured 50 oocysts and sporocysts from 2 infected $L$. californicus and our measurements are nearly identical to those reported in the original description by Liburd and Mahrt.'" However, we noticed a few minor differences between our oocysts and theirs: (1) we never saw a polar granule; (2) the oocyst wall was thinner at one end; and (3) the oocyst wall was composed of 2 layers. The first difference can be explained by oocyst age. The oocysts we saw were measured when 1593 days old; Liburd and Mahrt $1: 2$ noted that polar granules "were seldom seen in older oocysts." The other two observations add new structural information 
to the species description. We also provide photomicrographs of $E$ lophortygis not present in the original description (Figs. 4, 5).

Eimeria okanaganensis (Fig. 6)

Remarks. We only measured a few of these oocysts from $L$. californicus and they conformed to the size range provided in the original description. ${ }^{12}$ We also provide a photomicrograph of $E$. okanaganensis not present in the original paper. It clearly shows the unique curved anterior end of the sporocysts of this species (Fig. 6).

Eimeria oreortygis sp. n. (Figs. 7-9)

Description. Oocyst ellipsoid to slightly ovoid; wall $\sim 1.5$ consisting of 2 layers: outer $\sim 2 / 3$ of total wall thickness, smooth, pale blue; inner layer smooth, thin, yellowish; micropyle absent although wall is slightly thinner at 1 end (Figs. 7, 9); oocyst residuum present as a few refractile granules (Fig. 8); polar granule absent; sporulated oocysts $(\mathrm{N}=50) 24.4 \times 18.7(21-28 \times 17-23)$ with $\mathrm{L}: \mathrm{W}$ ratio 1.30 (1.16-1.50); sporocysts ovoid $14.1 \times 7.2(13-16 \times 6-9)$ with L:W ratio 1.96 (1.70-2.23); Stieda and substieda bodies present (Figs. 7-9); sporocyst residuum as compact mass $\sim 3$ $\times 4$ or as granules that obscure sporozoites when scattered throughout sporocyst; sporozoites with 1 or 2 refractile bodies. The oocysts were 1505 days old when measured.

Type Host. Oreortyx pictus (Douglas, 1829): mountain quail.

Type Locality. Monterey County, California.

Location in Host. Unknown; oocysts recovered from feces.

Etymology. The specific name is derived from the generic name of the host.

Remarks. This species closely resembles both $E$. lophortygis and $E$. okanaganensis in size and shape of the oocyst and sporocysts, but differs from both by the presence of a substieda body in the sporocysts, a distinctly twolayered oocyst wall, and the presence of a small oocyst residuum.

Isospora sp. (Fig. 10)

Description. Oocyst spherical or nearly so; wall $\sim 1.6$ composed of 2 layers: outer $\sim 2 / 3$ of total wall thickness, smooth, yellow; inner layer smooth, thin, green; micropyle and oocyst residuum absent; 2 polar bodies present each $\sim 1 \times$ 4; sporulated oocysts $(\mathrm{N}=25) 27.8 \times 25.0$ $(24-31 \times 23-29)$ with $\mathrm{L}: \mathrm{W}$ ratio 1.11 (1.0$1.20)$; sporocysts ovoid $16.9 \times 11.3(14-20$ $\times 10-13)$ with L:W ratio 1.50 (1.33-1.78); Stieda and substieda bodies present (Fig. 10 ); sporocyst residuum as granules of various sizes often obscuring sporozoites; sporozoites each with 2 refractile bodies. The oocysts were 1430 days old when measured.

Type Host. Oreortyx pictus (Douglas, 1829): mountain quail.

Type Locality. Monterey County, California.

Location in Host. Unknown; oocysts recovered from feces.

Remarks. There have been a number of isosporans (I. bellericae, I. gallinae, $I$. gallinarum, I. heissini, I. lyruri, I. mayuri, $I$. sp.) described from galliform birds, but most authorities argue the validity of many of these species, which closely resemble I. lacazei structurally, must be confirmed by cross-transmission experiments. Isospora lacazei has been described from over 50 species of passeriform birds and has also been given other names when its oocysts are found in transit through the gut of other birds and mammals. For example, Levine and Mohan "1" found it in the feces of six animals from three herds of beef cattle in central Illinois. They were about to describe it as a new bovine coccidium when they noticed the unmistakable similarity to $I$. lacazei. In a previous paper one of us studied the ultrastructure of the oocyst wall of I. lacazei. ${ }^{1 *}$ Since we still had our stock solution of oocysts originally isolated from sparrows, we 

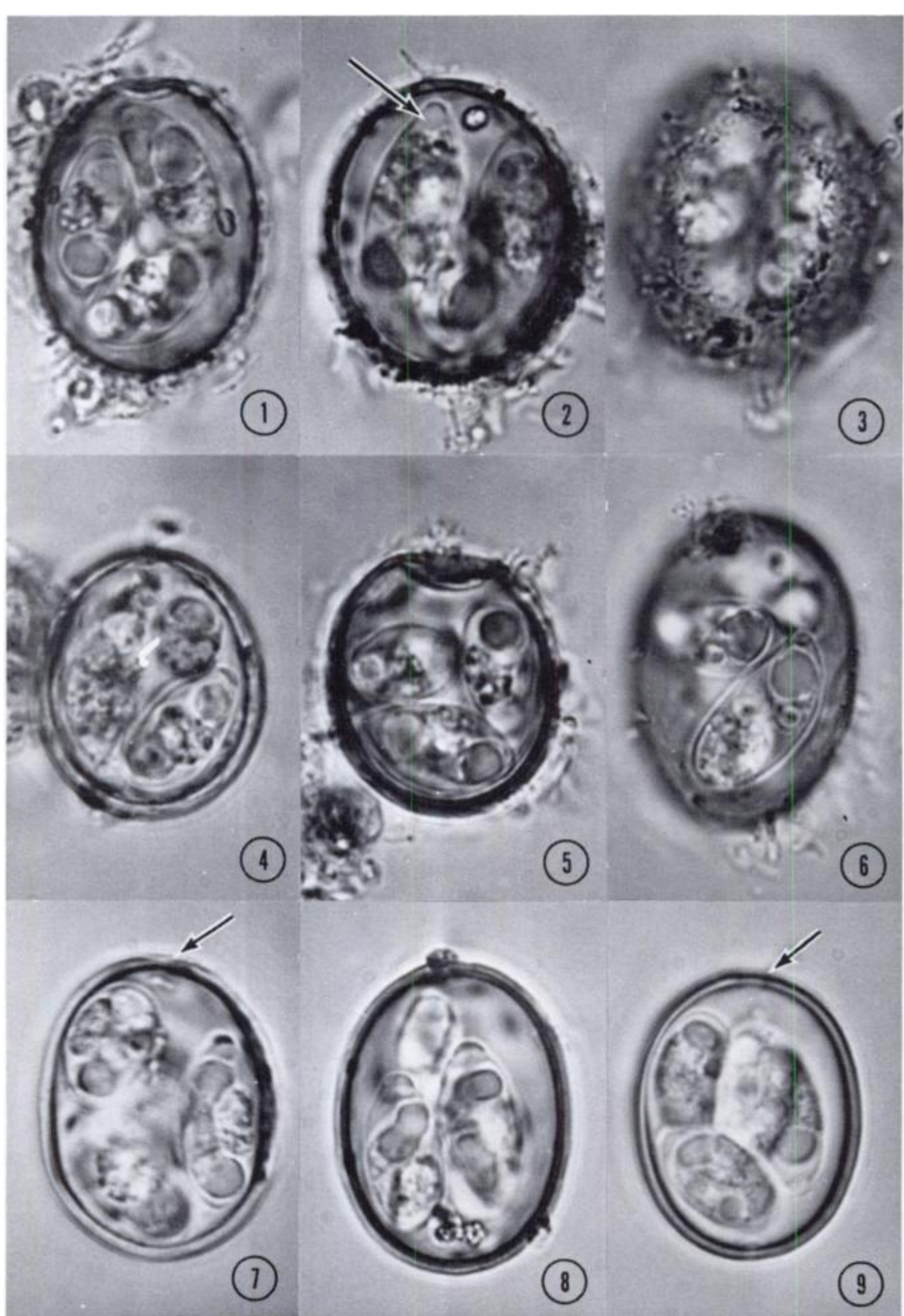

FIGURES 1-9. Sporulated oocysts of Eimeria crustisp. n. (1-3), Eimeria lophortygis (4, 5), Eimeria okanaganensis (6), and Eimeria oreortygis sp. n. (7-9). $\times 1300$. FIG. 1. Sporocyst residuum and polar body are clearly seen. FIG. 2. Note substieda body 
(arrow). FIG. 3. Outer wall is rough and irregularly sculptured. FIGS. 4, 5. Note apparent thinness of one end of oocyst; crenation in 5 due to length of time in sugar solution. FIG. 6. Note unique curved end of sporocyst in this species. FIGS. 7-9. Note sporocyst residuum (7), oocyst residuum (8), substieda body (7-8), and slight thinning of oocyst wall (arrows 7,9).

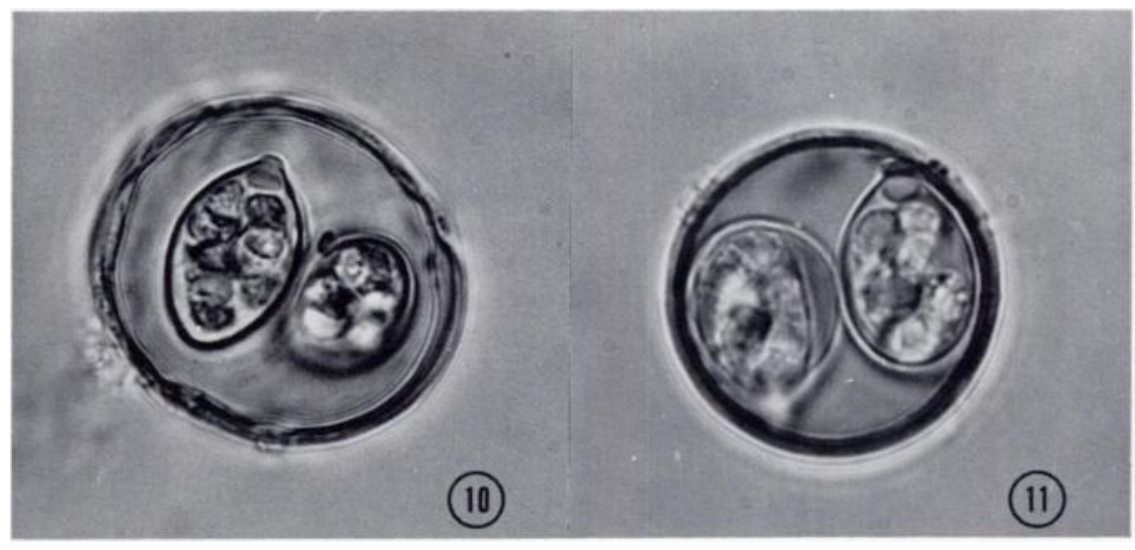

FIGURES 10, 11. Sporulated oocysts of Isospora sp. recovered from feces of 20 . pictus in this study (10) and of Isospora lacazei (11) from feces of sparrows from a previous study. ${ }^{18}$ Note similarities of size and structure.

measured and photographed oocysts of $I$. lacazei and found they differed very little in size (oocysts $26.6 \times 24.9$; sporocysts $17.2 \times 11.0)$ or structure from those recovered from $O$. pictus (cf Figs. 10, 11). Because of these similarities we are reluctant to give specific status to the isosporan we found in $O$. pictus. Rather, we agree with previous authors ${ }^{10,16,20}$ that isosporans which resemble $I$. lacazei, regardless of the host they were isolated from, should be regarded as provisional until firm experimental evidence can establish their specific status.

\section{Hosts}

Only 18 of $121(14.9 \%)$ quail collected from their natural environments and examined for coccidia had patent infections when collected. The hosts examined and their active coccidian infections were as follows:
Callipepla squamata (Vigors, 1830): scaled quail

None of 12 birds examined had patent infections when they were collected. Five birds ( 1 female, 4 immatures) were shot in Luna County, two immatures in Bernalillo County and five immatures in Roosevelt County, New Mexico in December, 1975.

Colinus virginianus (Linnaeus, 1758): bobwhite quail

None of 10 birds ( 1 male, 4 females, 5 immatures) examined had patent infections when they were collected. All birds were shot in Roosevelt County, New Mexico in December, 1975.

Cyrtonyx montezumae (Vigors, 1830): harlequin quail

None of 20 birds ( 1 female, 3 males, 16 immatures) examined had patent infections when they were collected. All birds were shot in Santa Cruz County, Arizona in January, 1976. 
Lophortyx californicus (Shaw, 1798): California quail

Nine of 35 birds (25.7\%) collected between February and August 1976 had patent coccidian infections. These in cluded 5 of 6 shot in February ( 3 males, 3 immatures), 2 of 9 shot in April ( 1 female, 2 males, 6 immatures), 2 of 8 shot in May (3 males, 3 females, 2 immatures), 0 of 3 shot in June (1 female, 2 immatures), 0 of 3 shot in July (1 male, 2 immatures), and 0 of 6 shot in August ( 1 female, 5 males). Five of the infected birds (1 male, 1 female, 3 immatures) had only $E$. lophortygis, 2 (males) had only $E$. oreortygis and 2(1 male, 1 immature) had both coccidians. All birds were shot in Monterey County, California.

Lophortyx gambelii Gambel, 1843: Gambel's quail

Fifteen birds ( 3 males, 5 females, 7 immatures) were shot in Luna County, New Mexico during December, 1975. Al were counted as negative for coccidia although samples from three birds had a very few, mostly unsporulated, oocysts that resembled $E$. lophortygis.

Oreortyx pictus (Douglas, 1829): mountain quail

These birds were sympatric with $L$. californicus $^{3}$ and 9 of $29(31.0 \%)$ shot between February and August 1976 had patent coccidian infections. These included 1 of 2 shot in February (1 male, 1 immature), 0 of 5 shot in April ( 1 female, 2 males, 2 immatures), 1 of 6 shot in May (3 males, 3 females), 2 of 3 shot in June (1 female, 2 males), 3 of 7 shot in July (1 female, 5 males, 1 immature), and 2 of 6 shot in August ( 2 males, 4 females). Two of the infected birds ( 1 male, 1 female) had only E. oreortygis, 1 (male) had only E. okanaganensis, 1 (female) had only $E$. crusti, 2 (1 male, 1 female) had only Isospora sp., 2 (1 female, 1 immature) had $E$. crusti and $E$. oreortygis and 1 (immature) had $E$. okanaganensis, $E$. oreortygis and E. lophortygis. All birds were shot in Monterey County, California.

\section{DISCUSSION}

Eimeria dispersa was the first coccidian to be described from a quail when Tyzzer ${ }^{23}$ reported it from the bobwhite, $C$. virginianus. Since then 10 other eimerians have been described from quail including $E$. colini and $E$. sp. from the bobwhite, ${ }^{2,17,25} \quad E$. bateri, $E$. taldykurganica, E. tsunodai and $E$. uzura from the Japanese quail, $C$. coturnix, ${ }^{1,13,19,21,22}$ E. lophortygis and $E$. okanaganensis from the California quail, L. californicus ${ }^{12}$ and $E$. crusti and $E$. oreortygis from mountain quail, $O$. pictus (this study). Earlier, Henry claimed to have found $E$. acervulina, $E$. mitis and E. tenella in California and mountain quail and Venard ${ }^{24}$ stated that $E$. acervulina and $E$. tenella occurred in the bobwhite. In view of crosstransmission studies done by others $^{6,15,23}$ and of our current ideas about host specificity among bird eimerians we agree with Levine $^{9}$ and others ${ }^{16,20}$ that it is unlikely for chicken coccidians to infect quails which are only rather distantly related to them. However, it is not unusual for eimerians to infect different species of closely related genera and in our study we found three of the four eimerians previously described from California and mountain quail were shared between these sympatric hosts. Since the ranges of the two hosts overlap, the possibility always exists that the apparent cross-transmission of eimerians between host genera might be spurious. Unfortunately, this cannot be ruled out because of our collection methods.

The true prevalence of coccidian infections in wild populations of quail in the U.S. is still unclear, as is the importance of environmental and host factors that contribute to the variations seen in these infections. Surveys have recorded an incidence of coccidians in different quail populations that varies from zero to $97 \%, 5,6,8,14$ but most authors omit much of the following information: (1) the specific identity of the coccidians; (2) the 
number of birds examined; (3) the dates the samples were collected; (4) the age and sex of the birds examined; (5) the methods used to make diagnosis; (6) the prevalence of infection in the sample population; and (7) an estimate of the severity of the infection. Only Herman and Chattin ${ }^{7}$ and Liburd, ${ }^{11}$ surveying $L$. californicus in California and south central British Columbia, respectively, provided information on prevalence, host age and sex, and severity of infection.

With the exception of O'Roke, ${ }^{14}$ other studies have found a much higher overal incidence of coccidian infections in quail (usually $>60 \%$ ) than the $15 \%$ in our study. ${ }^{5,7,11}$ From our data and that of others, ${ }^{5,7,11}$ it is clear the prevalence of coccidial infections in quail varies within a single area at different periods, between areas during the same time period and between host species in the same area and time period. For example, Herman and Chattin ${ }^{7}$ and Herman et al. found the highest prevalence of eimerian infection in L. californicus from California to occur from October through May whereas Liburd" found the highest prevalence of infection in L. californicus from British Columbia to occur in August and September. In both instances the highest prevalence of infection occurred when adults were raising broods: April and May in California and August and September in British Columbia. Liburd" also suggested the higher overall prevalence of infection in California birds reflected the moist weather of coastal California. In our study only $26 \%$ of the L. californicus from California had patent eimerian infections and the incidence of infection was higher from February through May (9 of 23, 39\%) than from June through August (0 of 12). On the other hand, O. pictus - which was sympatric with $L$. californicus - had a higher infection rate during July and August (5 of 13, 38\%) than from February through May (2 of 13, 15\%). None of the birds we examined had heavy infections, as judged from the small number of oocysts in all samples, nor were there age or sex differences apparent in the birds we sampled. Both the California and Mountain quails were collected from sympatric populations during the cool, wet breeding season, yet the number of birds infected in each sample was lower than in most other reports. Finally, the scaled quails collected in New Mexico were sympatric both with the bobwhites and the Gambel's quails. Electrophoretic studies on enzymes from these three hosts ${ }^{4}$ indicates they are equally closely related. All three species were collected during the cold, dry, non-breeding season (December, January), when incidence of infection is normally high in other quails, ${ }^{i, 8}$ but no hosts were found to be infected. Restraints, less obvious than climate, host sex, age and breeding condition, must be operating in this hostparasite system, but these remain to be determined. We can only conclude from all available data that coccidiosis does not appear to be a major disease problem among wild quail populations in the United States.

\section{LITERATURE CITED}

1. BHATIA, B.B., T.P. PANDEY, and B.P. PANDE. 1965. Eimeria bateri n. sp. from Indian common grey quail (Coturnix coturnix coturnix). Ind. J. Microbiol. 5: 61-64.

2. FISHER, J.W. and G.L. KELLEY. 1977. The sporulated oocyst of Eimeria colini sp. n. from the bobwhite quail, Colinus virginianus. J. Parasit. 63: 200-202.

3. GUTIÉRREZ, R.J. 1980. Comparative ecology of the Mountain and California quail in the Carmel Valley, California. In: The Living Bird. Cornell Lab. Ornith. 18: 71-93. 
4. - and S.Y. YANG. Protein variation and systematic relationships of some galliform birds. Auk. In review.

5. HENRY, D.P. 1931. Species of coccidia in chickens and quail in California. Univ. Calif. Publ. Zool. 36: 157-170.

6. HERMAN, C.M. 1949. Coccidiosis in native California valley quail and problems of control. Ann. N.Y. Acad. Sci. 52: 621-623.

7. — and J.E. CHATTIN. 1943. Epidemiological studies on coccidiosis of California quail. I. Occurrence of Eimeria in wild quail. Calif. Fish Game 29: 168-179.

8. - H.A. JANKIEWICZ and R.W. SAARNI. 1942. Coccidiosis in California quail. Condor 44: 168-171.

9. LEVINE, N.D. 1953. A review of the coccidia from the avian orders Galliformes, Anseriformes and Charadriiformes, with descriptions of three new species. Am. Midl. Nat. 49: 696-707.

10. - and R.N. MOHAN. 1960. Isospora sp. (Protozoa: Eimeriidae) from cattle and its relationship to I. lacazei of the English sparrow. J. Parasit. 46: 733741.

11. LIBURD, E.M. 1969. Incidence of coccidia in California quail (Lophortyx californicus) from the Okanagan Valley, British Columbia. Can. J. Zool. 47: 645-648.

12. and J.L. MAHRT. 1970. Eimeria lophortygis n. sp. and E. okanaganensis n. sp. (Sporozoa: Eimeriidae) from California quail Lophortyx californicus in British Columbia. J. Protozool. 17: 352-353.

13. NORTON, C.C. and M.A. PEIRCE. 1971. The life cycle of Eimeria bateri (Protozoa: Eimeriidae) in the Japanese quail Coturnix coturnix japonicum. J. Protozool. 18: 57-62.

14. O'ROKE, E.C. 1928. Parasites and parasitic diseases in the California Valley Quail. Calif. Fish Game 14: 193-198.

15. PATTERSON, F.D. 1933. Cross infection experiments with coccidia of birds. Cornell Vet. 23: 249-253.

16. PELLÉRDY, L.P. 1974. Coccidia and Coccidiosis. Verlag Paul Parey, Berlin. $959 \mathrm{p}$.

17. PROSTOWO, B.P. and S.A. EDGAR. 1970. Preliminary report on a new coccidium of bobwhite quail, Eimeria sp. n. (Protozoa: Eimeriidae). Poultry Sci. 49: 1428-1429.

18. SPEER, C.A., A.A. MARCHIONDO, B. MUELLER and D.W. DUSZYNSKI. 1979. Scanning and transmission electron microscopy of the oocyst wall of Isospora lacazei. Z. Parasitenkd. 59: 219-225.

19. SVANBAEV, S.K. and M.K. UTEBAEVA. 1973. Coccidial infections of Phasianus colchicus mongolicus and Coturnix coturnix in Kazakhstan (in Russian). Akad. Nauk Kazakhsk. SSR, s. Biol. 6: 62-68.

20. TODD, JR., K.S. and D.M. HAMMOND. 1971. Coccidia of Anseriformes, Galliformes, and Passeriformes. In: Infectious and Parasitic Diseases of Wild Birds. J.W. Davis, R.C. Anderson, L. Karstad, D.O. Trainer, eds. Iowa St. Univ. Press, Ames. pp. 234-281.

21. TSUNODA, K. and Y. MURAKI. 1971. A new coccidium of Japanese quails: Eimeria uzura sp. nov. Jap. J. vet. Sci. 33: 227-235. 
22. TSUTSUMI, Y. 1972. Eimeria tsunodai sp. nov. (Protozoa: Eimeriidae) a cecal coccidium of Japanese quails (Coturnix coturnix japonica). Jap. J. vet. Sci. 34: 1-9.

23. TYZZER, E.E. 1929. Coccidiosis in gallinaceous birds. Am. J. Hyg. 10: 269-383.

24. VENARD, C. 1933. Helminths and coccidia from Ohio bobwhite. J. Parasit. 19: 205-208.

25. WAGGONER, R.E. 1967. Description of an unidentified species of Eimeria in the bobwhite quail. Dis. Abstr. "B" 28: 3949B.

Received for publication 12 December 1980 